\title{
Development and vigor of diploid and tetraploid Russian wildrye seedlings
}

\author{
JOHN D. BERDAHL AND RONALD E. RIES
}

Authors are research geneticist and rangeland scientist, USDA-ARS, Northern Great Plains Research Laborutory, P.O. Box 459, Mandan, N.D. S8554.

\section{Abstract}

Poor seedling vigor limits the use of Russian wildrye [Psathyrostachys juncea (Fisch.) Nevski] for complementary pasture. Tetraploid $(2 n=4 x=28)$ plants of Russian wildrye have greater seedling vigor in greenhouse studies when compared to plants with the normal diploid chromosome complement $(2 n=2 x=14)$. Objectives of this research were (i) to compare seedling emergence and development of diploid and tetraploid Russian wildrye in solid-seeded, single-row field plots and (ii) to document early seedling development and morphology in a controlled environment chamber. Seed mass averaged $2.70 \mathrm{mg} \mathrm{seed}^{-1}$ for diploids and $4.66 \mathrm{mg}^{-1}$ seed ${ }^{-1}$ for traploids. Initial seedling emergence averaged approximately $33 \%$ greater for tetraploids than diploids for both early and late field planting dates. Tiller number averaged only slightly, and generally not significantly, greater for diploids than tetraploids (maximum difference of $\mathbf{0 . 3}$ tillers plant ${ }^{-1}$ ) in solid-seeded rows in the field. Seedling height was consistently greater for tetraploids than diploids, a result of greater leaf length. Larger leaf size did not result in fewer leaves or in slower leaf development for tetraploids. Seedling emergence from a $63 \mathrm{~mm}$ depth in a controlled environment chamber averaged $46 \%$ for tetraploids and $10 \%$ for diploids at a $16 / 13^{\circ} \mathrm{C}$ diurnal temperature regime and 11 and $6 \%$, respectively, for tetraploids and diploids at a $23 / 18^{\circ} \mathrm{C}$ temperature regime. Coleoptile length averaged $61 \mathrm{~mm}$ for tetraploids and $49 \mathrm{~mm}$ for diploids at the $16 / 13^{\circ} \mathrm{C}$ temperature regime and 42 and $43 \mathrm{~mm}$ for tetraploids and diploids, respectively, at the $23 / 18^{\circ} \mathrm{C}$ temperature regime. Tetraploid Russian wildrye provides a unique germplasm pool from which additional improvement in seedling vigor can be accomplished beyond the limits that are possible from continued selection in diploid germplasm.

Key Words: Psathyrostachys juncea, seedling emergence, coleoptile length, seedling tillers, Haun score.

Russian wildrye [Psathyrostachys juncea (Fisch.) Nevski] is an introduced, cool-season, bunchgrass with broad adaptation to semiarid regions of North America (Rogler and Schaaf 1963, Smoliak and Johnston 1980). Russian wildrye produces an abundance of basal leaves that maintain relatively high levels of

USDA/ARS Northern Plains Area, is an equal opportunity/affirmative action employer and all agency services are available without discrimination. The authors gratefully acknowledge technical assistance provided by Becky Wald, Curtis Klein, and Anne Haakenson.

Manuscript accepted 23 Mar. 1996

\section{Resúmen}

El débil vigor de establecimiento de sus plantulas limita el uso del centeno silvestre ruso (Psathyrostachys juncea), para su utilización en praderas complementarias. Las plantas tetraploides $(2 n=4 x=28)$ del centeno silvestre ruso poseen un mayor vigor en el establecimientos de las plantulas en estudios de invernadero al ser comparadas con plantas con el complemento normal diploide de cromosomas $(2 n+2 x=14)$. Los objetivos de esta investigación fueron: 1) el comparar la emergencia de las plantulas y el desarrollo de centeno silvestre ruso diploide y tretaploide en una siembra en surcos. 2) el documentar el desarrollo de las plantúlas y su morfologia en una cámara de ambiente controlado. La masa de la semilla promedio que de $2.70 \mathrm{mg}$ para las variedades diploides y $4.66 \mathrm{mg}$ para las tetraploides. La emergencia de las plantulas inciales promedió, aproximadamente un $33 \%$ más para las tretaploides que para las diploides, tanto para fechas de siembra tempranas, como tardias. El numero de tallos promedio fue solo ligeramente mayor para los diploides más no significativo, que para los tetraploides (diferencia máxima de 0.3 tallos por planta). La altura de las plantulas fue consistentemente mayor para los tetraploides que para las diploides, como resultado de una mayor longitud de hoja. El mayor tamaño de hoja no resulto en menos hojas o en un desarrollo lento de la hoja para los trataploides. La emergencia de las plantulas de una profundidad de $63 \mathrm{~mm}$ en una cámara de ambiente controlado, promedio $46 \%$ para los tretaploides y $10 \%$ para los diploides en un régimen de temperatura diurna de $16 / 13^{\circ} \mathrm{C}$ y 11 y $6 \%$ respectivamente para tretaploides y diploides en un régimen de temperaturas de $23 / 28^{\circ} \mathrm{C}$. La longitud del coleoptilo promedio $61 \mathrm{~mm}$ para los tretaploides y $49 \mathrm{~mm}$. para los diploides en el regimen de temperatura $16 / 13^{\circ} \mathrm{C}$ y 42 y $43 \mathrm{~mm}$. para los tetraplnides y diplnides, respectivamente, en el régimen de temperatura de $23 / 18^{\circ} \mathrm{C}$. El centeno silvestre ruso tretaploide suministra un conglomerado (pool) de germoplasma único, mediante el cual se puede obtener un mejoramiento adicional del vigor de las plantulas, más alla de los limites posibles de la selección continuada de germoplasma diploide.

digestibility and protein with advancing maturity (Knipfel and Heinrichs 1978). The specics provides valuable pasture that is often used to complement native rangeland during the late- summer and fall when nutritive quality of most forages is relatively low.

Poor vigor during establishment is a major factor limiting more widespread use of Russian wildrye (Lawrence 1963). Genetic gain from selection for improved seedling vigor has been accomplished and is evident in diploid cultivars such as ' $\mathrm{Swift}$ ' (Lawrence 1979), 'Bozoisky-Select' (Asay et al. 1985), and 'Mankota' (Berdahl et al. 1992). Seedling vigor was greater for 
tetraploid than diploid Russian wildrye in greenhouse studies (Lawrence et al. 1990; Berdahl and Barker 1991; Jefferson 1993). An induced tetraploid cultivar of Russian wildrye with improved seedling vigor, 'Tetracan', has been licensed for sale in Canada (Lawrence et al. 1990).

Critical comparisons of seedling emergence and seedling development between diploid and tetraploid Russian wildrye have not been reported in field environments that are similar to those encountered by commercial producers. Also, seedling morphology and development at early stages determine the genetic potential for initial seedling emergence, and these parameters have not been defined for Russian wildrye in rigidly controlled environments. Objectives of this study were: (i) to compare seedling emergence and development of diploid and tetraploid Russian wildrye in solid-seeded plots in field studies, and (ii) to document early seedling development and morphology of diploid and tetraploid Russian wildrye in a controlled environment chamber.

\section{Materials and Methods}

\section{Plant Materials}

Three diploid entries, 'Vinall', 'Mankota', and Mandan R1831, and the 3 tetraploid entries, Mandan R4X28-23, Mandan R4X2911 , and Mandan R4X37-25, were included in this study. Even though a relatively small sample of germplasm was involved, none of the entries had parent clones in common. Vinall was developed by USDA-ARS at Mandan, N.D. and released in 1960 (Hein 1960). Mankota, also developed by USDA-ARS at Mandan, has improved seedling vigor and forage yield compared with Vinall and was released cooperatively by USDA-ARS, USDA-NRCS, and the North Dakota Agricultural Experiment Station in 1991 (Berdahl et al. 1992). Mandan R1831 is an experimental strain selected primarily for high seedling vigor and seed yield. The tetraploid strains were developed at Mandan using a nitrous oxide technique to double the chromosome number of diploid parents that were previously selected for high seedling vigor and overall plant vigor (Berdahl and Barker 1991). The tetraploid entries all had regular meiosis (Berdahl and Barker 1991). All seed was harvested from field plots near Mandan in 1988 and stored in a deep freeze at $-20^{\circ} \mathrm{C}$. Germination percentage, measured according to procedures of the Association of Official Seed Analysts (1981), and seed mass are recorded in Table 1.

Table 1. Germination percentage and seed mass of 3 diploid and 3 tetraploid Russian wildrye entries harvested in 1988 near Mandan, N.D.

\begin{tabular}{llcc}
\hline \hline Ploidy level & Entry & Germination $^{2}$ & Seed mass \\
\hline \multirow{2}{*}{ Diploid } & Vinall & $--(\%)--$ & $\left(\right.$ mg seed $\left.^{-1}\right)$ \\
& Mankota & $96.8 \mathrm{al}$ & $2.58 \mathrm{~d}$ \\
& Mandan R1831 & $94.0 \mathrm{ab}$ & $3.03 \mathrm{c}$ \\
Tetraploid & Mandan R4X28-23 & $97.5 \mathrm{a}$ & $2.48 \mathrm{~d}$ \\
& Mandan R4X29-11 & $87.5 \mathrm{c}$ & $4.45 \mathrm{~b}$ \\
& Mandan R4X37-25 & $95.0 \mathrm{ab}$ & $4.73 \mathrm{ab}$ \\
& & $95.0 \mathrm{ab}$ & $4.80 \mathrm{a}$ \\
\hline
\end{tabular}

Means followed by the same letter are not significantly different ( $\mathrm{P} \leq 0.05$ ) based on a Waller-Duncan K-ratio T test.

${ }^{2}$ Final germination counts were based on 4 replicates of 100 seeds germinated 14 days between 2 blotters in petri dishes maintained at $20 / 30^{\circ} \mathrm{C}, 16 / 8$ hour photoperiod, according to procedures of the Association of Official Seed Analysts (1981).

\section{Field Study}

A site near Mandan, N.D. $\left(46^{\circ} 55^{\prime} \mathrm{N}, 100^{\circ} 55^{\prime} \mathrm{W}\right)$ at an altitude of $500 \mathrm{~m}$ with a Parshall fine sandy loam soil (coarse-loamy, mixed Pachic Haploborolls) was chosen for the field study. The site had been fallowed the previous year and was cultivated, harrowed, and hand-raked prior to planting. Planting dates were 25 April and 24 May 1991 and 4 May and 10 June 1992, which provided a relatively early and a relatively late planting date within each year for the northern Great Plains region. The 6 entries, 3 diploid and 3 tetraploid, were replicated 6 times in a randomizedcomplete-block design. Each of the 4 plantings was randomized separately. Each plot consisted of a single row $2 \mathrm{~m}$ long with a $0.5 \mathrm{~m}$ spacing between plots. Planting depth was controlled by pressing a $2.5 \times 2.5 \mathrm{~cm} \times 2.0 \mathrm{~m}$ marker into the soil to create a $2.5 \mathrm{~cm}$ furrow for each row. Each plot was hand-planted with 100 seeds spaced $\approx 2.0 \mathrm{~cm}$ apart. Planted furrows were carefully covered with soil. A person with a mass of $80 \mathrm{~kg}$ packed each row by placing a piece of wooden plywood $(2.0 \mathrm{~m} \times 45 \mathrm{~cm} \times 1.25 \mathrm{~cm}$ thick) over the row and walking on the plywood. The study received only natural precipitation and no fertilizer. Rainfall for 60 days immediately following each planting date was adequate and well-distributed, totaling $97 \mathrm{~mm}$ for the 25 April 1991, 126 $\mathrm{mm}$ for 24 May 1991, $139 \mathrm{~mm}$ for 4 May 1992, and $182 \mathrm{~mm}$ for the 10 June 1992 plantings.

Seedling emergence was measured at 2- or 3-day intervals on an entire plot and data were adjusted according to percentage pure live seed. Tiller number, Haun score, and seedling height were measured at 7-day intervals on a subsample of 5 randomly selected seedlings per plot. The primary tiller of each of the 5 seedlings in each subsample was marked with a chicken leg-band and used for repeated measurements of Haun score (Haun 1973) and plant height. All seedlings remained vegetative during the growing season immediately after planting; thus, Haun score described seedling development stages numerically according to number of leaves present. Seedling height was measured as distance from ground level to the tip of the last fully expanded leaf, extended vertically.

\section{Growth Chamber Study}

Seedling emergence and coleoptile length were measured on the same 3 diploid and 3 tetraploid entries in a growth chamber study. Two planting depths, 25 and $63 \mathrm{~mm}$, and 2 diurnal temperature regimes, $23 / 18^{\circ} \mathrm{C}$ and $16 / 13^{\circ} \mathrm{C}$, with a $14 / 10$-hour photoperiod were investigated. Light radiation at soil level was $900 \mu \mathrm{mol}$ $\mathrm{m}^{-2} \mathrm{~s}^{-1}$. An experimental unit for each of the 6 entries consisted of 10 seeds planted in a PVC cylinder measuring $5.2 \mathrm{~cm}$ inside diameter by $20 \mathrm{~cm}$ high. Soil was a Parshall fine sandy loam (coarse-loamy, mixed Pachic Haploborolls) packed in each cylinder to a bulk density of $1.4 \mathrm{~g} \mathrm{~cm}^{-3}$ with a field capacity of $24 \%$ soil water by volume. Each cylinder was watered to field capacity after planting with a $50 \%$ Hoagland's solution containing $0.1 \mathrm{~g} \mathrm{~N}$ liter $^{-1}$. Cylinders were brought to field capacity with tap water the second day. Thereafter, cylinders were watered to maintain $50 \%$ available water ( $17 \%$ soil water by volume) and brought to field capacity with $50 \%$ Hoagland's solution once weekly.

Soil was washed from developing seedlings 17 days after planting for the $23 / 18^{\circ} \mathrm{C}$ temperature regime and 19 days after planting for the $16 / 13^{\circ} \mathrm{C}$ regime. Coleoptile length was measured as total distance of the coleoptile tip above the seed, regardless of whether the coleoptile had emerged from the soil surface. 


\section{Statistical Analysis}

Separate ANOVA's were first run on each of the 4 field plantings. Means and variances were similar within the early and within the late planting dates for the 2 years. Separate ANOVA's for the early and late dates were combined over years. Entries and years were considered as random effects in the statistical model that included replicates/years, entries, years, entries $X$ years, and entries $X$ replicates/years as sources of variation. Entry $X$ year interaction effects were tested for significance using the expected mean square for entry $X$ replicate/year as the error term. Entry effects were tested using entry $X$ year as the error term, and differences among ploidy levels were tested using a single degree of freedom comparison. Each successive measurement for specific seedling traits over the growing season was treated as a separate variable. Differences in Haun scores between early and late planting dates were tested for significance using a $t$-test of unpaired observations.

The 2 ploidy levels, 2 planting depths, and 2 temperature regimes in the growth chamber study were analyzed as a completely randomized design arranged in a $2 \times 2 \times 2$ factorial with 3 replicates. The 3 diploid and 3 tetraploid entries were treated as subsamples/ploidy level. Ploidy level, planting depth, and temperature regime were all considered to have fixed effects in the ANOVA, and all main effects and interaction effects were tested using the expected mean square for replicates/ploidy level $X$ planting depth $X$ temperature regime as the error term. Since most of the interaction effects for seedling emergence and coleoptile length were significant, simple effects of ploidy level were examined within each level of planting depth and temperature regime. Differences in seedling emergence between temperature regimes were tested for significance for diploids and tetraploids using a ttest of unpaired observations.

\section{Results and Discussion}

\section{Seedling Emergence}

Stebbins (1971) reported that increased cell size associated with higher ploidy levels resulted in improved seedling vigor in many diploid species. Lawrence et al. (1990) and Berdahl and Barker (1991) attributed improved seedling emergence of tetraploid over diploid Russian wildrye in greenhouse studies primarily to greater seed mass for tetraploid germplasm. Seed mass in this study averaged $2.70 \mathrm{mg} \mathrm{seed}^{-1}$ for diploids and $4.66 \mathrm{mg} \mathrm{seed}^{-1}$ for tetraploids (Table 1), a $72 \%$ increase in seed mass for tetraploid over diploid entries. Entry $\times$ year-and ploidy level $X$ year-interaction effects for seedling emergence in this field study were low and were not significant for any of the seedling counts within early and late planting dates. Patterns of seedling establishment were different for the 2 planting dates. Initially, seedling emergence was greater $(\mathrm{P}<0.01)$ for tetraploids than diploids in both the early (Table 2$)$ and late (Table 3 ) plantings. In early plantings, tetraploids averaged more $(\mathrm{P}<0.01)$ live seedlings than diploids on all observation dates over a 34-day period. Emergence occurred more rapidly in late plantings, and seedling counts were similar for diploids and tetraploids during a 14 to 26 -day period after planting. Stand density of established seedlings was excellent for both diploids and tetraploids for the 2 planting dates in both years of this study.

Diploid and tetraploid seedlings emerged differently from a deep planting $(63 \mathrm{~mm})$ in the 2 controlled temperature regimes (Table 4). When the diurnal temperature regime was decreased from $23 / 18^{\circ} \mathrm{C}$ to $16 / 13^{\circ} \mathrm{C}$ (14/10 hours light/dark), seedling emergence did not increase significantly for diploids and increased dramatically from 11.1 to $45.7 \%$ ( $P \leq 0.01)$ for tetraploids. Coleoptile length measured from the $63 \mathrm{~mm}$ planting depth also increased when temperature was reduced, and the relative increase was much greater for tetraploids than diploids. Time from planting to emergence for tetraploids at the $63 \mathrm{~mm}$ depth averaged 7.5 days for the $23 / 18^{\circ} \mathrm{C}$ temperature regime and 15.2 days for the $16 / 13^{\circ} \mathrm{C}$ temperatures. Increased coleoptile length at lower temperatures was the most logical reason for improved emergence of tetraploids from deep planting. Tetraploids likely have a greater potential coleoptile length than diploids because of the greater seed mass and increased cell size in tetraploid plants. McElgunn and Lawrence (1970) reported that emergence of diploid Russian wildrye seedlings was severely impeded beyond a 45-mm planting depth, and they attributed this failure to emerge to inadequate elongation of the coleoptile. Although an emerging

Table 2. Means for seedling traits of 3 diploid and 3 tetraploid Russian wildrye entries averaged over early field plantings made 25 April 1991 and 4 May 1992 near Mandan, N.D.

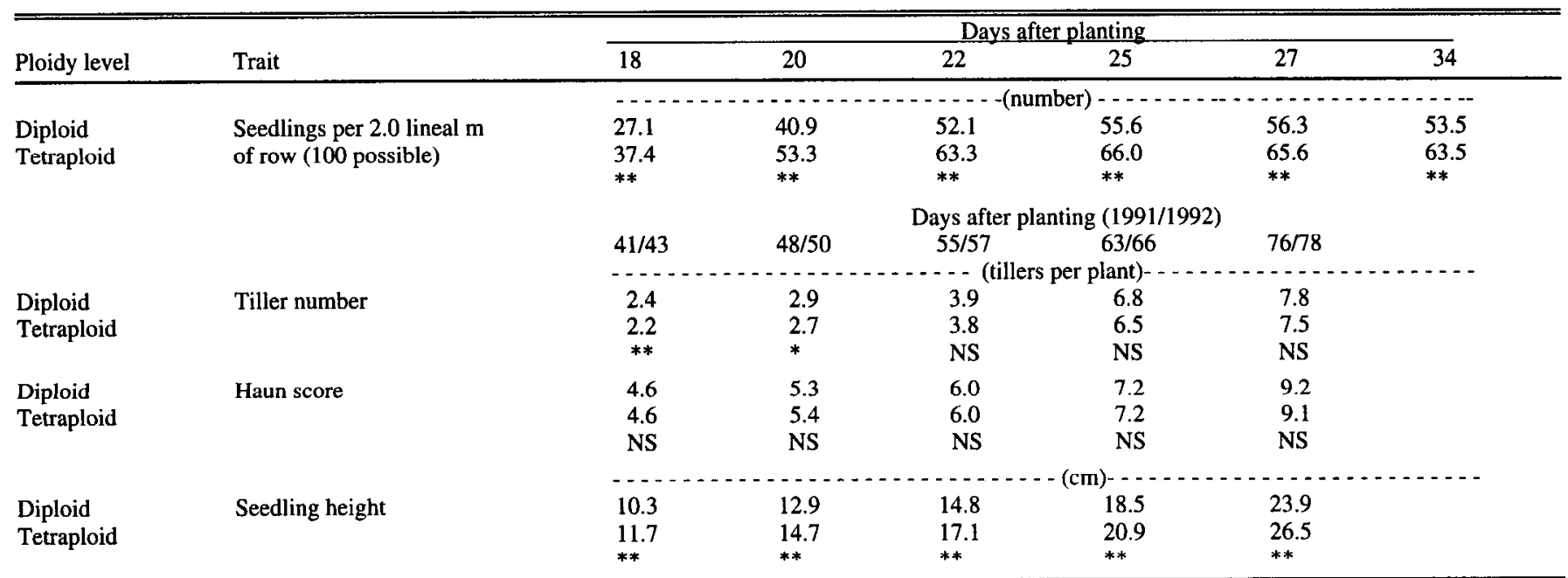

*, **Differences significant at $\mathrm{P} \leq 0.05$ and $\mathrm{P} \leq 0.01$, respectively. NS = Not significant 
Table 3. Means for seedling traits of 3 diploid and 3 tetraploid Russian wildrye entries averaged over late field plantings made 24 May 1991 and 10 June 1992 near Mandan, N.D.

\begin{tabular}{|c|c|c|c|c|c|c|c|}
\hline \multirow[b]{2}{*}{ Ploidy level } & \multirow[b]{2}{*}{ Trait } & \multicolumn{6}{|c|}{ Days after planting } \\
\hline & & 12 & 14 & 17 & 19 & 21 & $\overline{26}$ \\
\hline \multirow[t]{2}{*}{$\begin{array}{l}\text { Diploid } \\
\text { Tetraploid }\end{array}$} & $\begin{array}{l}\text { Seedlings per } 2.0 \text { lineal } \mathrm{m} \\
\text { of row ( } 100 \text { possible) }\end{array}$ & $\begin{array}{l}26.7 \\
34.3 \\
* *\end{array}$ & $\begin{array}{l}63.6 \\
66.3 \\
\text { NS }\end{array}$ & $\begin{array}{l}66.7 \\
68.3 \\
\text { NS }\end{array}$ & $\begin{array}{l}\ldots 6.5 \\
67.4 \\
\text { NS }\end{array}$ & $\begin{array}{l}\ldots 4.1 \\
65.6 \\
\text { NS }\end{array}$ & $\begin{array}{l}61.6 \\
63.1 \\
\text { NS }\end{array}$ \\
\hline & & $\begin{array}{c}40 / 43 \\
-\ldots\end{array}$ & $47 / 50$ & $\begin{array}{r}\text { Days aft } \\
54 / 57 \\
-\end{array}$ & $\begin{array}{c}(1991 \\
61 / 64 \\
\text { plant)- }\end{array}$ & $68 / 66$ & $\ldots$ \\
\hline $\begin{array}{l}\text { Diploid } \\
\text { Tetraploid }\end{array}$ & Haun score & $\begin{array}{l}4.9 \\
4.8 \\
\text { NS }\end{array}$ & $\begin{array}{l}5.8 \\
5.8 \\
\text { NS }\end{array}$ & $\begin{array}{l}6.7 \\
6.7 \\
\text { NS }\end{array}$ & $\begin{array}{l}7.3 \\
7.3 \\
\text { NS }\end{array}$ & $\begin{array}{c}7.9 \\
7.8 \\
\text { NS }\end{array}$ & \\
\hline $\begin{array}{l}\text { Diploid } \\
\text { Tetraploid }\end{array}$ & Seedling height & $\begin{array}{l}12.5 \\
13.9 \\
* *\end{array}$ & $\begin{array}{l}14.0 \\
15.4 \\
* *\end{array}$ & $\begin{array}{l}15.4 \\
17.0 \\
* *\end{array}$ & $\begin{array}{l}16.5 \\
18.1 \\
* *\end{array}$ & $\begin{array}{l}17.1 \\
18.7 \\
* *\end{array}$ & \\
\hline
\end{tabular}

*, **Differences significant at $P \leq 0.05$ and $P \leq 0.01$, respectively. NS $=$ Not significant.

seedling is primarily dependent on the rigid coleoptile for penetration through soil, the first true seedling leaf also is capable of limited penetration. The coleoptile did not penetrate to the soil surface for many tetraploid seedlings at the $63-\mathrm{mm}$ planting depth (data not presented). In some instances, seedling emergence was dependent on coleoptile development plus elongation and soil penetration by the first true seedling leaf. Mesocotyls of the diploid or tetraploid seedlings were not elongated at the $63-\mathrm{mm}$ planting depth, in contrast to a report by Rogler (1954) that a small percentage of crested wheatgrass [Agropyron desertorum (Fischer ex Link) Schultes] seedlings developed an elongated mesocotyl when seeded deeply.

Although caution must be used in extending results from controlled environment studies to the field, the potential for tetraploids to emerge from deeper plantings than diploids in a controlled environment has important implications. Deeper planting depths would place seeds and, subsequently, seedling crowns at deeper depths where extremes in soil water and temperature would be reduced. Also, improved coleoptile growth and seedling emergence for Russian wildrye at lower temperatures suggests that, aside from soil water availability, establishment potential may be improved by early spring planting when average temperatures are lower. Relationships between seedling development and temperature in Russian wildrye require further investigation.

\section{Tiller Development}

Tiller number tended to be only slightly higher for diploid than tetraploid seedlings in competitive sward conditions in the field (Tables 2 and 3). Jefferson (1993) found that seedlings of the tetraploid Russian wildrye cultivar Tetracan had significantly fewer $(P<0.01)$ and larger $(P<0.01)$ tillers than the diploid cultivars Swift and 'Mayak' in a greenhouse study. The relative magnitude of the difference between diploids and tetraploids in tiller number was much greater in the greenhouse study (Jefferson 1993) than in our field study. The greenhouse environment may have allowed fuller potential expression of tiller number than solid-seeded rows in the field where interplant competition was high. We have observed that mature tetraploid plants generally produce fewer tillers with a greater culm diameter than diploids in space-plant field nurseries. The potential for high tillering capacity may be important in a bunchgrass such as Russian wildrye in situations when plant density in field plantings is less than optimum. Thus, high tillering capacity may be an important selection criterion in improving tetraploid Russian wildrye through plant breeding.

\section{Haun Scores}

Frank et al. (1985) reported a linear relationship between rate of phyllochron development (addition of new leaves) and accumulation of heat units (growing degree-days) in 4 cool-season forage grass species. Temperatures were higher after the late than the early planting dates. Eight weeks after planting, Haun scores (a measure of leaf number) averaged 6.7 for the late and 6.0 for the early planting dates, a significant difference $(\mathrm{P}<0.01)$ (Tables 2 and 3). No differences in Haun scores were found between diploid and tetraploid seedlings at either planting date. Similar rates of leaf development for diploid and tetraploid seedlings, even though tetraploids had larger leaves, suggest that reproductive tillers of diploid and tetraploid Russian wildrye may also develop at similar rates.

Table 4. Seedling emergence percentage and coleoptile length of 3 diploid and 3 tetraploid Russian wildrye entries grown under 2 temperature regimes at 2 planting depths in a growth chamber.

\begin{tabular}{|c|c|c|c|c|c|}
\hline \multirow[b]{3}{*}{ Ploidy level } & \multirow[b]{3}{*}{ Trait } & \multicolumn{4}{|c|}{ Temperature and light regime } \\
\hline & & \multicolumn{2}{|c|}{$\begin{array}{c}23 / 18^{\circ} \mathrm{C}, 14 / 10 \text { hours } \\
\text { Planting depth } \\
\end{array}$} & \multicolumn{2}{|c|}{$\begin{array}{l}16 / 13^{\circ} \mathrm{C}, 14 / 10 \text { hour } \\
\text { Planting depth }\end{array}$} \\
\hline & & $25 \mathrm{~mm}$ & $63 \mathrm{~mm}$ & $25 \mathrm{~mm}$ & $63 \mathrm{~mm}$ \\
\hline $\begin{array}{l}\text { Diploid } \\
\text { Tetraploid }\end{array}$ & Emergence & $\begin{array}{l}85.3 \\
85.3 \\
\text { NS }\end{array}$ & $\begin{array}{l}5.7 \\
11.1 \\
* *\end{array}$ & $\begin{array}{c}76.6 \\
87.7 \\
*\end{array}$ & $\begin{array}{l}-.- \\
10.0 \\
45.7 \\
* *\end{array}$ \\
\hline $\begin{array}{l}\text { Diploid } \\
\text { Tetraploid }\end{array}$ & Coleoptile length & $\begin{array}{l}29 \\
30 \\
\text { NS }\end{array}$ & $\begin{array}{l}43 \\
42 \\
\text { NS }\end{array}$ & $\begin{array}{l}31 \\
31 \\
\text { NS }\end{array}$ & $\begin{array}{l}49 \\
61 \\
* *\end{array}$ \\
\hline
\end{tabular}

${ }^{*},{ }^{* *}$ Differences between ploidy levels significant at $\mathrm{P} \leq 0.05$ and $\mathrm{P} \leq 0.01$, respectively. NS $=$ Not significant 


\section{Plant Height}

Although the magnitude of the differences was not great, tetraploid seedlings were consistently taller than diploids $(\mathrm{P}<0.01)$ at all measurement dates for both the early and late plantings (Tables 2 and 3). Seedling height reflects leaf length, which would be expected to be greater in tetraploids due to increased size of plant cells. Large leaves provide a visual impression that tetraploid seedlings are much more vigorous than diploids. Large leaf size may be important in assimilating total carbon and in providing competition for weeds. Seedling counts began to decline approximately 4 weeks after planting for the early planting date and 3 weeks after the late planting date (Tables 2 and 3 ), probably due primarily to high interplant competition. The rate of decline in live secdlings was relatively low and similar for diploids and tetraploids.

\section{Conclusions}

Jefferson (1993) pointed out that diploid Russian wildrye cultivars selected for improved seedling vigor are still inferior to crested wheatgrass (Agropyron spp.) in stand establishment capability. Consequently, the majority of producers in semiarid regions of the Canadian Prairies continue to use crested wheatgrass for reseeding marginal cropland to grass, even though established Russian wildrye pastures often produce greater animal gains. Increased size of plant cells, organs, and tissues in tetraploid compared to diploid Russian wildrye results in important changes in plant morphology. Tetraploids provide a new, unique germplasm pool for Russian wildrye and provide an opportunity to make substantial improvements in seedling vigor. Seed mass of tetraploid entries averaged $72 \%$ greater than diploid entries in this study. Coleoptilc length and scedling emergence were much greater for tetraploids than diploids at a $63-\mathrm{mm}$ planting depth in a controlled environment chamber. Initial seedling emergence was more rapid for tetraploids than diploids in field studies with a planting depth of about $25 \mathrm{~mm}$. Seedling height was consistently greater for tetraploids, a result of increased leaf length. Larger leaf size did not result in reduced leaf number or slower development of leaves. Diploid seedlings may have the potential to develop more tillers than tetraploids, but diploids averaged only slightly more tillers, usually not significant, than tetraploids in solid-seeded rows in field studies.

\section{Literature Cited}

Asay, K.H., D.R. Dewey, F.B. Gomm, D.A. Johnson, and J.R. Carlson. 1985. Registration of 'Bozoisky-Select' Russian wildrye. Crop Sci. 25:575-576.

Assoc. Official Seed Analysts. 1981. Rules for testing seeds. J. Seed Tech. 6(2):1-126. (1989 Revision).

Berdahl, J.D. and R.E. Barker. 1991. Characterization of autotetraploid Russian wildrye produced with nitrous oxide. Crop Sci. 31:1153-1155.

Berdahl, J.D., R.E. Barker, J.F. Karn, J.M. Krupinsky, R.J. Haas, D.A. Tober, and I.M. Ray. 1992. Registration of 'Mankota' Russian wildrye. Crop Sci. 32:1073.

Frank, A.B., I.D. Berdahl, and R.E. Barker. 1985. Morphological development and water use in clonal lines of four forage grasses. Crop Sci. 25:339-344.

Haun, J.R. 1973. Visual quantification of wheat development. Agron. J. 65:116-119.
Hein, M.A. 1960. Registration of varieties and strains of other grasses, IV. Vinall Russian wildrye (Reg. No. 5). Agron. J. 52:662.

Jefferson, P.G. 1993. Seedling growth analysis of Russian wildrye. Can. J. Plant Sci. 73:1009-1015.

Knipfel, J.E. and D.H. Ileinrichs. 1978. Nutritional quality of crested wheatgrass, Russian wildrye, and Altai wildrye throughout the grazing season in southwestern Saskatchewan. Can. J. Plant Sci. 58:581-582.

Lawrence, T. 1963. A comparison of methods of evaluating Russian wild ryegrass for seedling vigor. Can. J. Plant Sci. 43:307-312.

Lawrence, T. 1979. Swift, Russian wild ryegrass. Can. J. Plant Sci. 59:515-518.

Lawrence, T., A.E. Slinkard, C.D. Ratzlaff, N.W. Holt, and P.G. Jefferson. 1990. Tetracan, Russian wild ryegrass. Can. J. Plant Sci. 70:311-313.

McElgunn, J.D. and T. Lawrence. 1970. A minirhizotron for in situ observation of seedling development. Can. J. Plant Sci. 50:754-756.

Rogler, G.A. 1954. Seed size and seedling vigor in crested wheatgrass. Agron. J. 46:216-220.

Rogler, G.A. and H.M. Schaaf. 1963. Growing Russian wildrye in the western states. U.S. Dept. Agri. Leafl. 313. U.S. Govt. Printing Office, Washington, D.C.

Smoliak, S. and A. Johnston. 1980. Russian wildrye lengthens the grazing season. Rangelands 2:249-250.

Stebbins, G.L. 1971. Chromosomal evaluation in higher plants. Edward Arnold, Ltd., London. 